Article

\title{
Scrutiny or Complacency? Banking Union in the Bundestag and the Assemblée Nationale
}

\author{
Anna-Lena Högenauer \\ Institute of Political Science, University of Luxembourg, 4366 Esch-sur-Alzette, Luxembourg; \\ E-Mail: anna-lena.hoegenauer@uni.lu
}

Submitted: 14 December 2020 | Accepted: 2 March 2021 | Published: 27 May 2021

\begin{abstract}
The financial and eurozone crises highlighted the inadequacy of the original governance structures of the eurozone. In response, a range of reforms were launched, including the creation of a European banking union. In practice, some elements of the banking union were delayed by division among member states and the breakdown of the Franco-German motor, such as the question of the operationalization of the single resolution mechanism and fund or the deposit insurance scheme. In addition, eurozone governance-which would once have been regarded as a technocratic issue-became increasingly politicized. The aim of this article is to study the extent to which the banking union was scrutinized by parliament and to what degree this reflects material interests and ideas. For this purpose, it focuses on salience (i.e., how much attention the issue received) and polarization (i.e., the divergence of positions). The analysis of the resolutions and debates of the German Bundestag and French Assemblée Nationale, i.e., the parliaments of two key states in EU decision-making on banking union, finds that the German government was indeed closely scrutinized, whereas the French government was relatively unconstrained.
\end{abstract}

\section{Keywords}

banking union; European deposit insurance scheme; France; Germany; parliament; single resolution fund; single resolution mechanism; single supervisory mechanism

\section{Issue}

This article is part of the issue "Reforming the Institutions of Eurozone Governance" edited by Anna-Lena Högenauer (University of Luxembourg), David Howarth (University of Luxembourg) and Moritz Rehm (University of Luxembourg).

(C) 2021 by the author; licensee Cogitatio (Lisbon, Portugal). This article is licensed under a Creative Commons Attribution 4.0 International License (CC BY).

\section{Introduction}

The financial crisis of 2007 created high costs for taxpayers and led to a hike in sovereign debt when EU member states stepped in to recapitalize banks. The resulting frustration motivated policymakers to create a banking union. The goal was to stabilize the European banking system through stricter rules and capital requirements for banks, a more centralized banking supervision on the European level, a European approach to bank restructuring and resolution that would limit the burden on taxpayers, and a European deposit guarantee scheme that would protect savers (Howarth \& Quaglia, 2016b).

Despite broad agreement on the desirability of protecting savers and taxpayers, there were substantial dis- agreements on the details. Not all member states had been affected by the financial crisis to the same extent: some were able to bear the burden alone, while others could not. There was a risk that the costs and benefits of banking union would be unevenly distributed across member states, and that risk-averse banks might end up paying for risk-taking banks. Questions relating to the mutualization of risk, the inclusion of small and local banks in the scheme, and also the correct decisionmaking bodies became disputed. Franco-German leadership broke down as the two countries were on opposing sides on most questions (Schild, 2018). The two countries were nevertheless important in the negotiations due to their sheer size and economic weight (Cassell \& Hutcheson, 2019; Howarth \& Quaglia, 2013). This is 
particularly obvious in Germany's veto of the creation of a European deposit guarantee scheme, which is generally attributed to high domestic pressure (Schild, 2020).

In line with the aims of this thematic issue (Högenauer \& Rehm, 2021), the article aims to analyse the domestic politics of the banking union in France and Germany through the positioning of their parliaments and parties. To what extent did the two governments face parliamentary pressure to defend specific positions? To what extent did the parliamentary politics reflect the material interests of the country and/or public attitudes towards the issue? The analysis will focus on the Lower Houses, i.e., the Bundestag and the Assemblée Nationale (AN). The Lower Houses perform the main function of representing the national electorate. By contrast, the Upper Houses, the Bundesrat and the Senate are not directly elected and the Bundesrat's primary function is not to represent the electorate but the state governments. They are extremely diverse in their composition and powers.

The first question relates to literature that shows that Eurozone governance has become more salient and controversial among parliamentarians (Auel \& Raunio, 2014; Closa \& Maatsch, 2014; Högenauer, 2019; Wendler, 2014). As a result, national parliaments have become more assertive in their scrutiny of key EU and Eurozone decisions. The German Bundestag is particularly active on eurozone crisis policies and has extensive powers (Auel \& Höing, 2014; Auel, Rozenberg, \& Tacea, 2014; Höing, 2013; Moschella, 2017). The question is to what extent these dynamics led to a close scrutiny of banking union that could potentially constrain governments (Donnelly, 2018). This is highly relevant, as EU crisis policymaking has often been criticized for lacking democratic input and debate (e.g., Sebastiaõ, 2021). An answer to this question requires an examination of the parliamentary salience of banking union, the timing of debates and resolutions, and the polarization of debates. By parliamentary salience, we mean how frequently the issue is raised in debates (Hutter \& Grande, 2014; see also De Wilde, 2011; De Wilde, Leupold, \& Schmidtke, 2016). Polarization captures the extent to which actors adopt different positions on an issue. In this multi-level context, it can refer to either disagreement between different groups of MPs or the disagreement of national politicians with European proposals.

In addition, the timing of activities matters: If parliaments hope to influence European negotiations or to control the government's position, the debates would have to predate the adoption of the policy. If plenary debates occur after the decision, they are reactive and can at most comment on the performance of the government or indicate (dis)agreement with the policy, but they can no longer shape the policy.

The question about the extent to which the debates reflect ideas and economic interests will draw upon the societal approach as used by Schirm $(2011,2020)$ and Van Loon (2021). Schirm (2011, 2020) defines ideas as values held by the public. Material interests are determined by the relative weight of economic sectors. So far, existing studies often emphasize the importance of material interests or structural economic factors in explaining government positions in eurozone crisis decision-making (e.g., Tarlea, Bailer, \& Degner, 2019), for example, whether banks are largely domestically or foreign-owned (Spendzharova, 2014), on the role of bank capitalization levels and bank-industry ties (Howarth \& Quaglia, 2016a), and on the qualitative composition of the banking sector in terms of whether there be large national champions or decentralized networks of cooperative and savings banks (Commain, 2021). The qualitative composition is particularly important in the context of France (large champions) and Germany (networks of savings and cooperative banks) as it fuels different views on what type of bank should be covered by European mechanisms and how much they should contribute financially to the stabilization of the European banking sector. However, Van Loon (2021) shows that ideas and interests do not necessarily pull in opposite directions, but can potentially work to reinforce each other.

In this vein, the following sections will first provide a short overview of the main elements of banking union and the positions of the French and German governments. Then French and German ideas and interests with regard to banking union will be analysed based on existing surveys, the literature on the politicization of banking union, and structural economic factors. This is followed by a discussion of the data collection on parliamentary scrutiny and an analysis of the findings in terms of the salience and polarization of banking union in the Bundestag and the AN.

\section{Banking Union and Franco-German Divisions}

The decisions on banking union represent one of the biggest steps forward in European integration since the launch of EMU (Degner \& Leuffen, 2019; Epstein \& Rhodes, 2016).

In 2013, agreement was reached on the Single Supervisory Mechanism (SSM) for Eurozone banks: Located within the European Central Bank (ECB), it is responsible for the direct supervision of systemically relevant banks and banks with substantial cross-border activities, while other banks are supervised by national supervisors under the responsibility of the ECB (Gren, Howarth, \& Quaglia, 2015; Kern, 2014).

In 2014, the Single Resolution Mechanism (SRM) was established in order to reduce the costs of bank resolutions for taxpayers. The Single Resolution Board takes decisions for those banks supervised directly by the ECB. In the event of a resolution, the bank's shareholders and creditors are first bailed-in, then the national compartment of the Single Resolution Fund (SRF) steps in. The national compartments are financed by levies from national banks and are backed up by national credit lines from the member state. By 2023, the 
national compartments will be merged (Howarth \& Quaglia, 2016b).

In 2015, the European Commission planned the creation of a European Deposit Insurance Scheme (EDIS) with the aim of merging national deposit insurance schemes. However, this proposal was ultimately blocked by division in the Council (Cassell \& Hutcheson, 2019).

In European decision-making on banking union, the established pattern of Franco-German leadership on monetary policymaking was disrupted. The two countries were often on opposing sides of the argument (Schild, 2018). They disagreed on the purpose of banking union and the costs and benefits of banking union generated distributional conflict. In the absence of a Franco-German agreement, EU institutions filled the gap and provided supranational leadership (Nielsen \& Smeets, 2018), but some elements of banking union were delayed or blocked.

Disagreements emerged largely along two dividing lines: the extent of risk-sharing across member states and the centralization of decision-making (Cassell \& Hutcheson, 2019; Schild, 2018). France, Italy, and Spain pushed for a rapid move towards banking union to disrupt the feedback loop between banking crises and sovereigns: States tend to rescue national banks with public funds thereby potentially entering a public debt crisis, which then affects national banks, which hold public debt. Germany, on the other hand, wanted to avoid sharing the risks of bailouts in other Eurozone states and preferred to focus on avoiding future crises (Schild, 2018).

As a result, whereas France wanted the European banking supervision and resolution to cover all Eurozone banks, Germany wanted it to cover only on systemically relevant banks, rather than its smaller savings and cooperative banks. Domestically, there were doubts about whether the ECB was the ideal banking supervisor given the potential conflict of interest with its role in monetary policy (cf. Högenauer, 2019), but the government ultimately agreed that the ECB should take on this role. Where France wanted the European Commission to play a key role in the restructuring and resolution of banks, Germany preferred a network of national resolution authorities (cf. Degner \& Leuffen, 2019). On this issue, Germany ultimately got its way in the form of a Single Resolution Board consisting of a Chair, four full-time members, and a representative of each national resolution authority. The Commission and Council of the EU would be able to veto Single Resolution Board decisions (Schild, 2018).

In addition, unlike France, Germany wanted to limit the use of public funds-and especially European funds-in the recapitalization of banks. As a result, whereas France favoured the use of the ESM to recapitalize banks with bad assets, Germany insisted that legacy assets should be a national responsibility and that the ESM should be used only for future crises. It also insisted on a recapitalization sequence: first private sharehold- ers, creditors and large depositors, then national resolution funds financed via bank levies, then national public capital, and then as a last resort, European capital from the ESM. The bailing in of private capital would reduce the burden on the taxpayer, and by asking for national recapitalization first, European risk-sharing would be limited. Germany also wanted to reduce the contribution from small banks, whereas France tried to limit the contributions from large banks, and there was disagreement on whether there should be a single resolution fund or a network of national funds. Finally, for the same reasons of aversion against the mutualization of risk, Germany vehemently blocked the creation of a EDIS using the argument that risks to bank's balance sheets would have to be reduced first (Schild, 2020).

\section{French and German Ideas and Interests on Banking Union}

The financial crisis harmed trust in the ECB. According to the 2010 Eurobarometer (European Commission, 2010), $45 \%$ of French and German respondents distrusted the ECB, but in Germany distrust was growing particularly fast. The same survey showed that support for European banking supervision, European supervision when public money was spent to rescue financial institutions, and regulation of the financial sector was higher in Germany (80\%, $80 \%$ and $77 \%$ respectively) than in France $(73 \%, 68 \%$ and $71 \%)$. As the eurozone crisis dragged on, German attitudes towards EU banking supervision became less positive, as did French attitudes: Eurobarometer 81 (European Commission, 2014) shows that $75 \%$ of German and $67 \%$ of French respondents were in favour of banking supervision.

Thus, the German public is actually more strongly in favour of the fundamental idea of a banking union, despite the negative debate in the media. These surveys do, of course, only capture very general attitudes and cannot provide information on the kind of banking supervision citizens want. Nevertheless, it is interesting that there is a disconnect between the reluctance of the German government in decision-making on banking union and the overwhelming support of Germans for the idea of European banking supervision.

In addition, the fact that there were only $4 \%$ of 'don't knows' by German and 13\% by French respondents on the question on banking supervision (European Commission, 2010) is an indication that the public considered this issue quite important. Schild (2018) argues that the German government-unlike the French parliament-was under particular pressure due to the high public salience of European policies, the predominantly negative attitudes towards solidarity between countries, and the emergence of a Eurosceptic right-wing party, the AfD. The public salience of EDIS was particularly high in Germany (Cassell \& Hutcheson, 2019). Kriesi and Grande (2016) also argue that politicization of eurozone crisis policies was particularly high in Germany, 
whereas politicization in France only reached $40 \%$ of the German level.

This is likely to influence parliamentary scrutiny: Baglioni and Hurrelmann (2016) argue that there are different arenas of politicization, such as the citizen arena, an intermediary arena for business groups or other specialized actors, and an institutional arena (e.g., a parliament). The different arenas are connected, in that public salience can raise the salience for politicians, and the strategies of politicians in parliaments can contribute to the (de)politicization of an issue (cf. Gheyle, 2019; Wendler, 2019). According to Gormley (1986), the complexity and public salience of an issue interact to create different policymaking dynamics. When complexity is high (as is the case with banking union) and public salience is low, politicians operate in 'board room' mode: Affected business groups can influence politics and politicians are free to make compromises as the media and public do not take much interest. However, in such a situation politicians deal with complex issues as little as possible, due to the absence of electoral incentives. When complexity and salience are both high, politics take place in 'operating room' mode: politicians are not free to make compromises, as the public has strong expectations and the media reports on the issue (although Gormley suggests that reporting is likely to be faulty). The problem with this typology is that its description of the dynamics does not entirely fit the European context, as there is an underlying assumption that difficult decision-making is delegated to agencies. In the EU context, however, the most contentious decisions often have to be taken at the level of the European Council or at least the Council of Ministers. As a result, high salience and complexity do not necessarily lead to delegation to bureaucrats. Banking union in practice corresponds better to Gormley and Boccuti's (2001) typology of issues based on conflict and public salience, where they argue that issues that governments insist on staying in control of issues that are salient and conflictual, whereas they involve stakeholders in issues that are high in conflict and low in salience. In the US case, the absence of conflict and salience results in the federal level having little interest in tightly controlling the state level. In our case, we assume that the incentives for parliamentary scrutiny are low. This is also in line with the argument by De Wilde et al. (2016) that politicization is driven by the critics rather than supporters of an issue. If we take conflict to mean the opposition to the European plans and/or conflict between domestic actors, this would mean that:

H1: Politicians take business interests on board when the public salience of the issue is low, but the conflict on the issue (e.g., between businesses and the EU) is high (expectation: Germany on SSM, SRF);

$\mathrm{H} 2$ : When both conflict and public salience are high, politicians take control of the decision, but have limited political room for manoeuvre (expectation: Germany on EDIS);

H3: When public salience and conflict are low (expectation: France, especially on the SSM, SRF, EDIS), parliamentarians will have no interest in the close scrutiny of executives;

$\mathrm{H} 4$ : Parliaments are more likely to be proactive in the face of high public salience.

However, the precise powers of the parliaments could be considered a mediating factor. While national parliaments have no direct influence over EU policymaking, they can put pressure on their national governments to represent the 'correct' position in the Council of the EU via committee and plenary debates (Raunio, 2009) and resolutions. In this context, a high level of activity is usually used to signal that the parliament considers the issue important. However, the AN has moderate scrutiny powers over EU affairs and is usually less active while the Bundestag has strong scrutiny powers and tends to be quite active (Auel et al., 2014). The Bundestag has control over the plenary agenda, whereas the French government had almost complete control over the plenary agenda of the AN until 2008/2009 (Auel \& Raunio, 2014). However, following constitutional amendments, the AN now controls roughly one-third of its agenda and can hold plenary debates on EU affairs if it sees fit. Indeed, it tends to schedule at least one EU debate per month (Thomas \& Tacea, 2014). In addition, the opposition has the right to table motions in both parliaments. In the case of the AN, there is a specific tool, 'European resolutions,' which can be adopted by the European Affairs Committee on virtually any EU document and which become final if the relevant sectoral committee does not counteract them (Thomas \& Tacea, 2014). In the case of the Bundestag, one-quarter of MPs can force the government to publicly explain why it deviated from a previously passed Bundestag resolution (Höing, 2015). Thus, while a lower number of AN plenary debates is to be expected given the influence of the government, the AN is not substantially weaker than the Bundestag with regard to resolutions. Substantial differences in activity have to be ascribed also to different levels of motivation. For example, Högenauer and Howarth (2019) have shown that the AN scrutinizes the Banque de France more actively than the Bundestag scrutinizes the Bundesbank, despite the fact that the Bundestag is also considered stronger than the AN outside EU affairs: Because it chooses to take an interest.

In terms of material interests, there are arguably two factors at play, the general divide between creditor and debtor states, and the composition of the banking sector. Thus, Lehner and Wasserfallen (2019; see also Wasserfallen, Leuffen, Kudrna, \& Degner, 2019) studied government positions on 47 issues of the Economic and Monetary Union (EMU) reform and found that the 
predominant dimension was between fiscal transfer (led by France) and fiscal discipline (led by Germany). This dimension had very strong explanatory power for several banking union-related issues, such as banking supervision, the build-up and mutualization of the SRF and the fiscal backstop for the SRF. The findings make sense in light of the high exposure of banks to domestic sovereign bonds. Both Ongena, Popov, and Van Horen (2016) and De Marco and Macchiavelli (2016) find that there is a 'moral suasion' mechanism whereby banks that are publicly owned or influenced by politicians (e.g., via the board of directors) collude with national governments and buy larger quantities of domestic sovereign bonds than would be in their interest. In the eyes of Germany, their high exposure to Spanish, Greek, and Italian banks could affect their stability and therefore the chances of other European banks having to step in with 'their' contributions to the proposed SRF or EDIS. For France, which started to experience rising public debt during the crisis, there was a correspondingly greater willingness to be more open to solidarity and transfers between countries.

Secondly, the banking sectors of France and Germany are structured differently, which also generates different material interests. The German banking sector is organized around three pillars (private banks, corporate banks, and savings banks) that often consist of smaller banks that focus on risk adverse operations and SMEs. The three pillars already had their own deposit insurance schemes in place, which reduced the perceived need for a European scheme (Zimmermann, 2013). In addition, the aim was to avoid the situation in which small, risk-averse banks might have to cover the losses of large risk-taking foreign banks. The situation was different for France, where it was attractive to place large national champions under a European scheme rather than to risk having to bail them out nationally (cf. Commain, 2021, on the French banking sector). On the whole, Zimmermann (2013) concludes that the existence of strong embeddedness of national deposit insurance schemes into different varieties of financial capitalism means that a common deposit insurance scheme is unlikely to emerge. The strong connections linking the banking sector to politicians in key countries such as Germany increase the ability of economic interests to influence policymaking.

\section{Data Collection}

The article analyses plenary debates and proposed resolutions from 1 January 2012 to 31 December 2016 covering the adoption of the first three pillars of banking union (SSM, SRM, SRF) and the blocking of EDIS. This period starts before the Commission proposal on the SSM and ends after a natural break in the data: There were no debates after February 2016 until 2018.

The analysis focuses on the plenary debates and proposed resolutions. Plenary debates fulfil a communication function: As they are more likely to attract media attention, parties and parliamentarians can use them to demonstrate to voters that they take a close interest in a certain topic and to communicate their stance on that topic. The minutes of Bundestag and AN plenary debates are published in full and are broadcast live on the internet and/or TV. Resolutions also make the parliament's or a party's position visible. By contrast, committee meetings tend to be much less visible (cf. Raunio, 2016). In addition, the finance committee of the Bundestag does not publish minutes and meetings are closed to the public.

Due to the different archival systems of the AN and the Bundestag, the relevant debates had to be selected following different strategies: In the case of the Bundestag, a keyword search of all plenary debates in that period was used to identify all debates where the SSM, the SRM, the SRF, or the deposit guarantee scheme were mentioned at least once. The German names of these policies were used as a search term. In a second step, plenary debates specifically on banking union were filtered out through a manual analysis of the titles and contents. This allowed us to identify 18 debates on banking union. The electronic archive of the AN does not allow for a keyword search of plenary debates but publishes the topics of the debates in an easy-to-browse format. Therefore, all debates that could potentially be on banking union were preselected. Then a manual analysis of the debates showed that only four were specifically on banking union. In both the Bundestag and the AN, one debate can cover several pillars of banking union.

In addition, a keyword search was used to identify relevant resolutions.

In order to measure the degree of polarization, i.e., the extent to which opinions diverge (De Wilde, 2011; De Wilde et al., 2016; Hutter \& Grande, 2014), three German debates on the SSM, the SRM/SRF, and EDIS were analysed in depth. In light of the limited number of French debates (and the fact that two were transposition debates), a debate on banking union is used to analyse the general position on the SSM and EDIS, while a second debate covers the SRF. The SRM and SRF are discussed together, as parliamentary debates usually treat them as linked. The selected debates are the earliest debates on the issue.

\section{Banking Union in the Bundestag and the Assemblée Nationale}

\subsection{Salience and Timing}

Figure 1 shows that banking union was indeed a salient topic for the German Bundestag from an early stage and that the interest was sustained over time and across the different policy elements: Banking union was discussed in 18 plenary debates, 13 of which were specifically on banking union and five of which were debates on Commission work programs or reports on the European Council that focused on banking union.

By contrast, in the AN, only four plenary debates focus on banking union. Two were implementation 


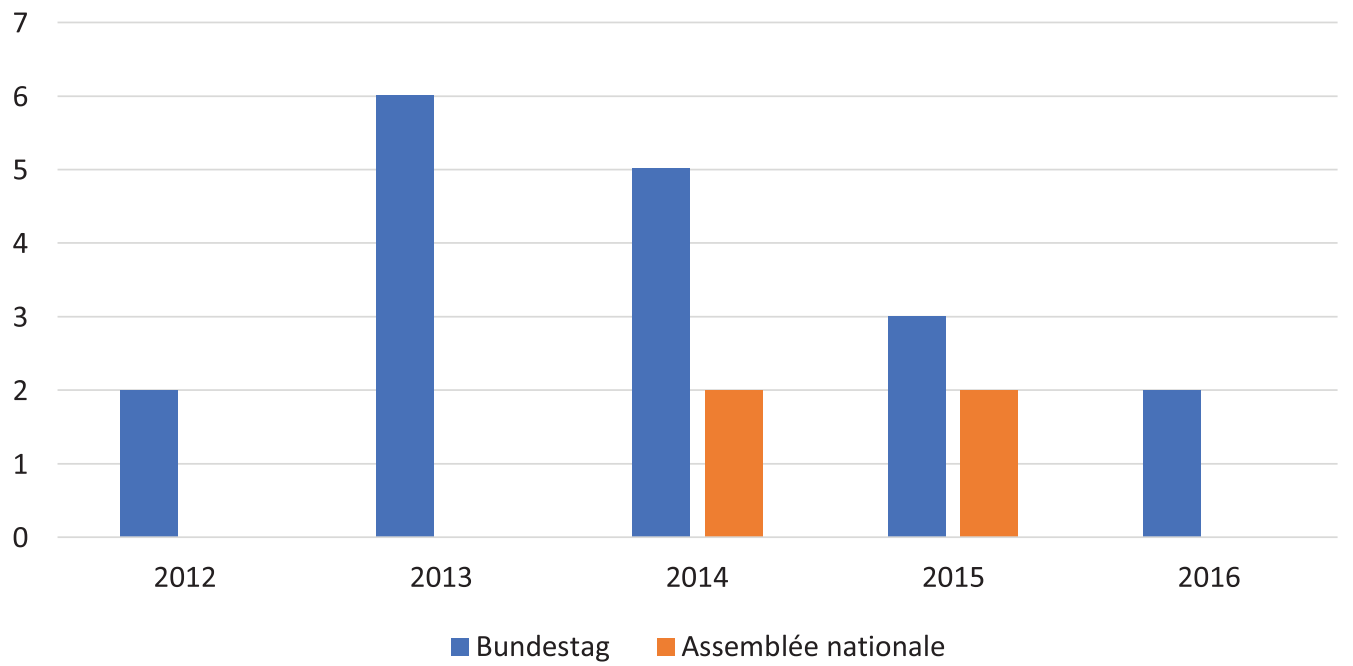

Figure 1. The number of plenary debates on banking union.

debates, one on banking union in general and one on the SRF. This is in line with $\mathrm{H} 3$ that public salience and parliamentary salience are linked and that low public salience provides low incentives for parliamentary scrutiny.

In addition, the AN's approach was reactive: Only AN debate 20140152 of 30 January 2014 on banking union contains a discussion of the SRF/SRM that predates the European decision (of July 2014). The other debates follow European decisions and comment on the government's and EU's performance after the facts. The Bundestag was far more proactive: The first EDIS debate of 5 November 2015 preceded the official Commission proposal of 24 November. Three SSM debates and four SRM/SRF debates predate the respective European decisions. There is thus a mix of German debates that formulate positions and debates that comment on outcomes. This confirms $\mathrm{H} 4$ that high public salience encourages politicians to be proactive (especially in the case of EDIS, where the Bundestag opposed faster than the European Commission could propose).

In addition, the AN adopted one cross-party resolution in January 2014 encouraging the creation of the SRM and SRF, the use of the ESM as a backstop, and the creation of a European deposit guarantee scheme in the long run. There was one further tabled resolution that was not adopted. By contrast, there were 19 tabled resolutions in the Bundestag, 15 failed opposition resolutions and four adopted government resolutions, confirming $\mathrm{H} 2, \mathrm{H} 3$, and $\mathrm{H} 4$ about the connection between public salience and parliamentary scrutiny (see Figure 2 ).

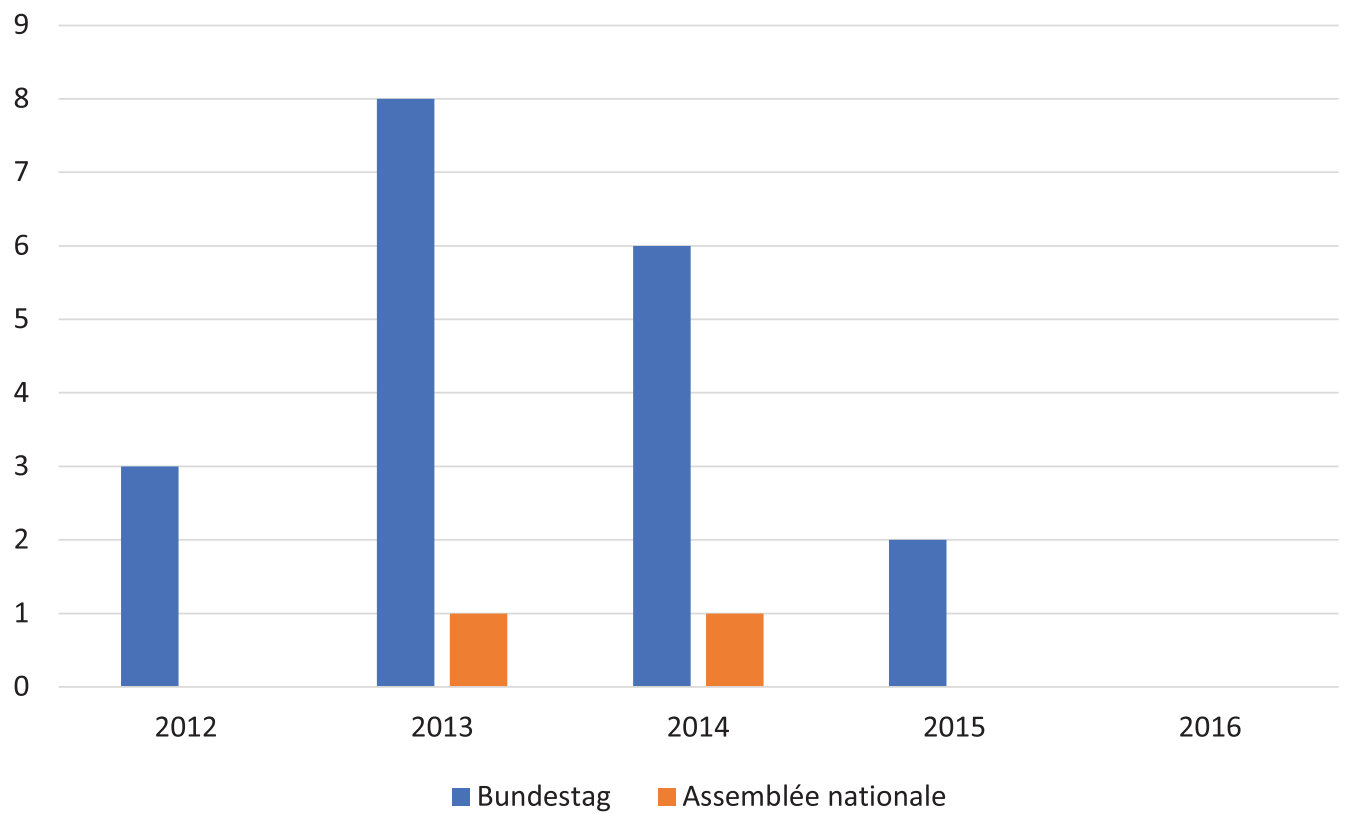

Figure 2. Proposed resolutions on banking union. 


\subsection{Framing and Polarization}

In order to gain greater insight into how the issue was framed by MPs, all plenary debates were analysed manually. Five representative debates are presented below: the two French debates on banking union and on the ratification of the SRF, and three Bundestag debates on the SSM, the SRM/SRF, and on EDIS.

This analysis shows two things: Firstly, the governing parties defend the European decisions and MPs praise the achievements of their governments-even in the case of Germany and the SRM/SRF, where the government was originally concerned about the mutualization of risk. The German opposition is prone to point out the flaws of decisions, such as the small size of the SRF. In France, where the government was eager to reach an agreement and public salience was low, in line with $\mathrm{H} 3$, there is no clear government-opposition divide on the European policies. Instead, government-opposition arguments focus on the national question of whether the size of the French banks should be reduced. $\mathrm{H} 2$ is correct in that the German government parties did assume an active role on the highly salient EDIS, which was disliked by the public and stakeholders, and rejected it even before the European Commission officially proposed it, leaving themselves little room for compromise. In line with $\mathrm{H} 1$, for the SSM and SRM/SRF, where German public opinion and economic interests were sceptical towards the EU's plans, but public salience was lower, the government parties took on board the interests of stakeholders and argued that these measures clearly should not apply to savings and cooperative banks. This is broadly in line with a survey of the preferences of French and German MPs on reforms to the EMU by Blesse, Boyer, Heinemann, Janeba, and Raj (2019) where French MPs were found to be more strongly in favour of new Eurozone competencies.

In addition, it is interesting to note that intraparty unity was extremely high in Germany across all parties and that the governing coalitions (CDU-FDP, then CDU-SPD) also spoke consistently with one voice. The German government did thus face a clear majority position that largely reflected its own demands, but also made it potentially difficult to compromise. The French government did not face comparable pressure: while all French parties wanted decisions as close as possible to the Commission proposals, the low number of debates and resolutions before decisions meant that the pressure was in practice much lower.

\subsubsection{The Positions on the Single Supervisory Mechanism}

AN debate 20140152 of 30 January 2014 on the progress of banking union and economic integration shows that all MPs welcomed banking union and the creation of the SSM, while criticism was limited to details and was not organized in a strong block of MPs. In line with $\mathrm{H} 3$, this positioning did not constrain the government. Among the most positive voices are Christophe Caresche (PS) who defended the choice of the ECB as supervisor and argued that the in-house separation would work and that the ECB had a vested interest in the success of banking union to maintain its credibility. Éric Alauzet (EELV) emphasized that banking supervision by the ECB would increase transparency. He only deplored that not all EU member states and banks were covered, and he would have liked to see a better involvement of the European Parliament to improve the democratic legitimacy of the process. Pierre Lequillier (UMP) also believed that the ECB would add clarity and independence to banking supervision, but would have liked national specificities to be taken into account. Valérie Rabault (PS) would have liked banking supervision to go further and to impose higher capital requirements in some cases.

However, Annick Girardin (Radical party of the left) criticized the complexity of the four different criteria to determine whether a bank falls under ECB supervision. Like Éric Alauzet, she wondered why banking supervision and banking resolution were not dealt with by the same institution, but she felt that the ECB was the wrong choice, due to crisis resolution having little to do with monetary policy, and that this new function could have undermined the independence and credibility of the ECB. Danielle Auroi (EELV) also opposed the appointment of the ECB as supervisor.

The Bundestag debated the SSM on 17 May 2013 (protocol 17241). The principle of European banking supervision was not particularly controversial. In fact, almost all speakers with the exception of Axel Troost (Die Linke) were in favour of European banking supervision. Troost also agreed in theory but felt that there were not enough guarantees that supervision would become stricter and better than the German Bafin. He also questioned art. 127 TFEU as a legal basis for banking union.

Polarization mostly existed on whether the ECB was an appropriate choice as banking supervisor and whether it would be able to neatly separate banking supervision and monetary policy in-house. As Manfred Zöllmer (SPD) argued, the ECB would be a business partner and creditor. By contrast, the MPs from the governing parties defended the ECB's ability to separate its two functions (e.g., Volker Wissing, FDP; Peter Aumer, CDU/CSU). Although Ralph Brinkhaus (CDU/CSU) did question the ability of the European Parliament to scrutinize the ECB in its role as banking supervisor. Institutionalized ideas about the importance of central bank independence thus played a role.

The other German plenary debates also show that the opposition (the Greens and Die Linke) questioned the choice of the ECB as supervisor, that the SPD maintained scepticism towards the ECB after it entered government in 2013 and that even CDU MPs argued, as late as 2016, that the ECB should eventually be replaced by a separate body. There was also broad agreement that European banking supervision should focus only on 
system-relevant banks, i.e., both government and opposition parties defended the same structurally relevant economic interests in line with $\mathrm{H} 1$.

\subsubsection{The Positions on the Single Resolution Mechanism and Single Resolution Fund}

In AN debate 20150219 of 5 May 2015 on the SRF agreement, all speakers supported the SRM and SRF's goal of breaking the feedback loop between bank failures and sovereign debt problems and of protecting the taxpayer from the costs of bank resolutions. As with the SSM, criticism focused less on the principle, but rather on the execution, and especially the German influence on the SRM and the SRF. It is clear that all speakers would have preferred a solution closer to the European Commission's proposals. Thus, Danielle Auroi (EELV) and Jacques Krabal (Radical party of the left) questioned the complexity of the SRM procedures and the multiple actors involved. Jérôme Chartier (UMP) questioned whether the resolution of a crisis within 48 hours was realistic given that systemic banks might have to produce 1,800 pages of resolution plans. Jean-Paul Dupré (Groupe socialiste, républicain et citoyen), wondered whether the non-participation of the UK and Sweden would weaken the positive effects of the SRM and SRF. The pressure on the government was again low.

A common theme taken up by almost all speakers is the size of the SRF, with the target of $€ 55$ billion being considered laughably small, unlikely to be able to support the failure of large banks and thus unable to truly protect taxpayers from the fallout of bank resolutions. Danielle Auroi (EELV) also demanded a faster mutualization of funds and criticized the national compartments. These two arguments reflect the importance of material interests, as France has a number of large banks that might be too big for the SRF, and the resolution of which would still have been costly for French taxpayers in a system based on separate national compartments. Similarly, several MPs specifically criticized the size of the French contributions to the SRF, which they regarded as too high given the low level of deposits (e.g., Jérôme Chartier, UMP; Jean-Christophe Fromantin, UDI). An exception was Éric Alauzet (EELV), who found that the high contributions of the French banks reflected the risks they took and their size. He argued that banks that are too big to fail have a responsibility towards the community.

The Bundestag debate on the SRM and the SRF of 14 March 2014 (protocol 18021) also shows that all speakers supported the basic principle of an SRM and SRF. The most critical speaker was Axel Troost (Die Linke), who liked the general idea but doubted that this specific system would be able to protect taxpayers. He questioned the ability of the SRF to handle a systemic crisis or even just the failure of a very large bank. He also argued that the current contributions to the national funds (including the German fund) were too small to add up to the target of the SRF. Another opposition MP,
Gerhard Schick (Bündnis 90/the Greens), criticized the complex decision-making structures of the SRM and SRF and the creation of national compartments within the SRF. He also questioned the use of an intergovernmental agreement as opposed to EU law.

By contrast, government MPs such as Klaus-Peter Flosbach (CDU/CSU) and Manfred Zöllmer (SPD) argued that the current set-up with national compartments and a longer period during which the fund would be filled struck a healthy balance, as very high levies on banks might choke off the supply of credit to the economy. Both Flosbach and Hans Michelbach (also CDU/CSU) argued that the absence of national compartments would lead to the communitarization of debt. This reflected both the material interests of German banks by preventing 'their' contributions to be used to bail out foreign banks and Germany's perspective as a creditor state wary of risksharing and financial transfers.

The SRF experiences moderate polarization along government-opposition lines: while all parties agreed on the basic idea of an SRF, the opposition (the Greens and Die Linke) would have preferred a much larger fund that would become operational far sooner. All German parties defended the savings and cooperative banks against forced participation in this scheme, though, which also reflects the importance of sectoral interests in line with $\mathrm{H} 1$.

\subsubsection{The Positions on European Deposit Insurance Scheme}

In AN debate 20140152 of 30 January 2014, MPs from virtually all parties demanded the creation of a European deposit insurance scheme. Valérie Rabault (PS) further specified that the Cypriot crisis showed that a mutualization of national guarantees was crucial for the avoidance of bank runs.

In the case of the Bundestag, the European Commission's musing on the possible introduction of a European deposit insurance scheme was first discussed in the debate of 5 November 2015 recorded in protocol 18133. The debate was short ( 25 minutes long) but heated. The first speaker, Antje Tillmann (CDU/CSU), praised the progress made in moving towards banking union and the European initiatives to stabilize the banking system and reduce the risks for taxpayers. But she also pointed towards the non-transposition of key elements by numerous states, e.g., the fact that only 17 states had implemented the Directive on bank resolutions despite a deadline of late 2014 , or the fact that only about half of the member states had transposed the Deposit Guarantee Directive. In addition, she pointed out that the first payments into the SRF were only due in 2016, and that banks had until 2024 to feed funds covering $0.8 \%$ of deposits into the system. She also felt that states still posed a risk to banks and vice versa. She concluded that the proposal for EDIS came too early and that national systems had to be fully operational first. This 
criticism was shared by Alexander Radwan (CDU/CSU), Manfred Zöllmer and Christian Petry (both SPD), who also opposed the communitarization of deposit insurance and suggested that the Commission should first control the national transposition of existing rules before it creates a new European system. They saw a risk that German savers would have to pay for mistakes in other countries. Radwan and Petry also argued that the risks across member states had to become more comparable. This reflects Germany's material interests as a transferadverse creditor state.

The fact that savings and cooperative banks should not be covered by EDIS was a concern shared by all politicians, even those in favour of EDIS. For example, Axel Troost (Die Linke)-usually not an ally of CDU, agreed that the local saving and cooperative banks should not be part of EDIS, because of the risk that their contributions would be used to save Zockerbanken (gambling banks) or large risk-taking banks abroad. However, he stated that he would be open to EDIS covering the same type of bank, and in that case, national funds could be used to support banks abroad. He also argued that a European system would be more effective to combat future crisis and that the larger German banks-like Deutsche Bankmight well require such a system themselves at some point. Gerhard Schick (Bündnis 90/the Greens) agreed that EDIS was the only means to avoid taxpayers having to cover the costs of bank failure if the national deposit guarantee system was insufficient, but he too would exclude savings and cooperative banks due to their distinctive features. Thus, sectoral interests were again strongly defended by both government and opposition parties in line with $\mathrm{H} 1$.

\section{Conclusion}

Overall, in line with our expectations, the higher public salience of banking union was reflected in a more proactive scrutiny in the Bundestag compared to the AN. While the AN only held four debates, two of which were concerned with implementation, the Bundestag organized 18 debates on banking union, with 19 tabled resolutions compared to two in the AN.

In addition, the polarization of banking union was higher in the Bundestag, where a governmentopposition divide existed especially in the case of the SRF. There was also some polarization on EDIS, but the importance of savings and cooperative banks meant that opposition MPs were also partially critical of EDIS. French MPs were generally highly supportive of banking union and most of their criticism was that integration did not go far enough. Differences between parties were comparatively minimal, and, in line with $\mathrm{H} 3$ and $\mathrm{H} 4$, the parliament was reactive and did not put much pressure on government.

The support for the position of the German government and the pressure to stick to it were both much higher compared to France. This is the result of the more proactive approach of the Bundestag with far more tabled resolutions and early debates. On the one hand, the government could lean on a cohesive majority, but on the other, the opposition closely scrutinized the government's performance and was quick to point out, for example, that the European decision to allow the ESM to recapitalize banks was a departure from the government's and parliament's previous line. The numerous (failed) tabled resolutions also hammered home certain points such as the opposition to the use of taxpayer money (e.g., the ESM) for the recapitalization or rescuing of banks, or the need to exclude the savings and cooperative banks from European banking supervision, the SRM/SRF, and EDIS.

Finally, it is clear that sectoral interests had considerable influence in both parliaments: In Germany, the interests of cooperative and savings banks were defended by both government and opposition parties. In addition, the material interests of Germany as a creditor country wary of financial transfers shaped its opposition to the mutualization of risks across states. Similarly, French support for a larger SRF and the mutualization of risk can be interpreted as a concern with the potentially high costs to the French taxpayer of resolving a large French national champion. The article thus agrees with the literature on the importance of structural interests in the creation of banking union. Ideas played a minor role, for example with regard to the importance of central bank independence in Germany. However, the debates do not reflect the fact that the German public is in fact more open towards the principle idea of European integration in this policy area than the French public.

\section{Acknowledgments}

The author wishes to thank David Howarth, Moritz Rehm, the participants of the online workshop "Reforming the institutions of euro-area governance" and four anonymous reviewers for their comments on previous versions of this article. This article benefitted from funding from the Institute of Advanced Studies of the University of Luxembourg under the EMULEG project.

\section{Conflict of Interests}

The author declares no conflict of interests.

\section{References}

Auel, K., \& Höing, O. (2014). Parliaments in the Euro crisis: Can the losers of integration still fight back? Journal of Common Market Studies, 52(6), 1184-1193.

Auel, K., \& Raunio, T. (2014). Debating the state of the Union? Comparing parliamentary debates on EU issues in Finland, France, Germany and the United Kingdom. Journal of Legislative Studies, 20(1), 12-28.

Auel, K., Rozenberg, O., \& Tacea, A. (2014). Measuring parliamentary strength and activity in EU affairs. In 
C. Hefftler, C. Neuhold, O. Rozenberg, J. Smith, \& W. Wessels (Eds.), The Palgrave handbook of national parliaments and the European Union (pp. 60-93). London: Palgrave Macmillan.

Baglioni, S., \& Hurrelmann, A. (2016). The Eurozone crisis and citizen engagement in EU affairs. West European Politics, 39(1), 104-124.

Blesse, S., Boyer, P. C., Heinemann, F., Janeba, E., \& Raj, A. (2019). European Monetary Union reform preferences of French and German parliamentarians. European Union Politics, 20(3), 406-424.

Cassell, M. K., \& Hutcheson, A. (2019). Explaining Germany's position on European Banking Union. German Politics, 28(4), 562-582.

Closa, C., \& Maatsch, A. (2014). In a spirit of solidarity? Justifying the European Financial Stability Facility (EFSF) in national parliamentary debates. Journal of Common Market Studies, 52(4), 826-842.

Commain, S. (2021). 'Don't crunch my credit': Member state governments' preferences on bank capital requirements. Politics and Governance, 9(2), 196-207.

De Marco, F., \& Macchiavelli, M. (2016). The political origin of home bias: The case of Europe (Working Paper No. 2016-060). Washington, DC: Finance and Economics Discussion Series.

De Wilde, P. (2011). No polity for old politics? A framework for analyzing the politicisation of European integration. Journal of European Integration, 33(5), 550-575.

De Wilde, P., Leupold, A., \& Schmidtke, H. (2016). Introduction: The differentiated politicisation of European governance. West European Politics, 39(1), 3-22.

Degner, H., \& Leuffen, D. (2019). Franco-German cooperation and the rescuing of the Eurozone. European Union Politics, 20(1), 89-108.

Donnelly, S. (2018). Advocacy coalitions and the lack of deposit insurance in Banking Union. Journal of Economic Policy Reform, 21(3), 210-223.

Epstein, R. A., \& Rhodes, M. (2016). The political dynamics behind Europe's new banking union. West European Politics, 39(3), 415-437.

European Commission. (2010). Standard Eurobarometer 73. Brussels: European Commission.

European Commission. (2014). Standard Eurobarometer 81. Brussels: European Commission.

Gheyle, N. (2019). Conceptualizing the parliamentarization and politicisation of European politics. Politics and Governance, 7(3), 227-236.

Gormley, W. T. (1986). Regulatory issue networks in a federal system. Polity, 18(4), 595-620.

Gormley, W. T., \& Boccuti, C. (2001). HCFA and the states: Politics and intergovernmental leverage. Journal of Health Politics, Policy and Law, 26(3), 557-580.

Gren, J., Howarth, D., \& Quaglia, L. (2015). Supranational banking supervision in Europe: The construction of a credible watchdog. Journal of Common Market Studies, 53, 181-199.
Högenauer, A. L. (2019). The politicisation of the ECB and the Bundestag. Politics and Governance, 7(3), 291-302.

Högenauer, A. L., \& Howarth, D. (2019). The parliamentary scrutiny of euro area national central banks. Public Administration, 97(3), 576-589.

Högenauer, A. L., \& Rehm, M. (2021). Reforming the institutions of Eurozone governance. Politics and Governance, 9(2), 159-162.

Höing, O. (2013). Differentiation of parliamentary powers: The German Constitutional Court and the German Bundestag within the financial crisis. In $\mathrm{M}$. Cartabia, N. Lupo, \& A. Simoncini (Eds.), Democracy and subsidiarity in the EU: National parliaments, regions and civil society in the decision-making process (pp. 255-280). Rome: II Mulino.

Höing, O. (2015). With a little help of the Constitutional Court: The Bundestag on its way to an active policy shaper. In C. Hefftler, C. Neuhold, O. Rozenberg, J. Smith, \& W. Wessels (Eds.), The Palgrave handbook of national parliaments and the European Union (pp. 191-208). London: Palgrave Macmillan.

Howarth, D., \& Quaglia, L. (2013). Banking Union as Holy Grail: Rebuilding the single market in financial services, stabilizing Europe's banks and 'completing' economic and monetary union. Journal of Common Market Studies, 51, 103-123.

Howarth, D., \& Quaglia, L. (2016a). The comparative political economy of Basel III in Europe. Policy and Society, 35(3), 205-214.

Howarth, D., \& Quaglia, L. (2016b). The political economy of banking union. Oxford: Oxford University Press.

Hutter, S., \& Grande, E. (2014). Politicising Europe in the national electoral arena: A comparative analysis of five West European countries, 1970-2010. Journal of Common Market Studies, 52(5), 1002-1018.

Kern, A. (2014). The ECB and banking supervision: Building effective prudential supervision? Yearbook of European Law, 33(1), 417-432.

Kriesi, H., \& Grande, E. (2016). The euro crisis: A boost to the politicization of European integration? In S. Hutter, E. Grande, \& H. Kriesi (Eds.), Politicising Europe: Integration and mass politics (pp. 240-276). Cambridge: Cambridge University Press.

Lehner, T., \& Wasserfallen, F. (2019). Political conflict in the reform of the Eurozone. European Union Politics, 20(1), 45-64.

Moschella, M. (2017). When some are more equal than others: National parliaments and intergovernmental bailout negotiations in the Eurozone. Government and Opposition, 52(2), 239-265. https://doi.org/ 10.1017/gov.2016.49

Nielsen, B., \& Smeets, S. (2018). The Role of EU institutions in establishing the banking union: Collaborative leadership in the EMU reform process. Journal of European Public Policy, 25(9), 1233-1256.

Ongena, S., Popov, A., \& Van Horen, N. (2016). The invisi- 
ble hand of the government: "Moral suasion" during the European sovereign debt crisis (Working Paper No. 1937). Frankfurt: European Central Bank.

Raunio, T. (2009). National parliaments and European integration: What we know and agenda for future research. Journal of Legislative Studies, 15(4), 317-334.

Raunio, T. (2016). The politicization of EU affairs in the Finnish Eduskunta: Conflicting logics of appropriateness, party strategy or sheer frustration? Comparative European Politics, 14, 232-252.

Schild, J. (2018). Germany and France at cross purposes: The case of Banking Union. Journal of Economic Policy Reform, 21(2), 102-117.

Schild, J. (2020). The myth of German hegemony in the euro area revisited. West European Politics, 43(5), 1072-1094.

Schirm, S. A. (2011). Varieties of strategies: Societal influences on British and German responses to the global economic crisis. Journal of Contemporary European Studies, 19(1), 47-62.

Schirm, S. A. (2020). Refining domestic politics theories of IPE: A societal approach to governmental preferences. Politics, 40(4), 396-412.

Sebastião, D. (2021). Covid-19: A different economic crisis but the same paradigm of democratic deficit in the EU. Politics and Governance, 9(2), 252-264.

Spendzharova, A. B. (2014). Banking union under construction: The impact of foreign ownership and domestic bank internationalization on European Union member states' regulatory preferences in banking supervision. Review of International Political Economy, 21(4), 949-979.

Tarlea, S., Bailer, S., \& Degner, H. (2019). Explaining governmental preferences on Economic and Monetary Union. European Union Politics, 20(1), 24-44.

Thomas, A., \& Tacea, A. (2014). The French Parliament and the European Union: 'Shadow control' through the government majority. In C. Hefftler, C. Neuhold, O. Rozenberg, J. Smith, \& W. Wessels (Eds.), The Palgrave handbook of national parliaments and the European Union (pp. 170-190). London: Palgrave Macmillan.

Van Loon, A. (2021). European financial governance: FTT reform, controversies and governments' responsiveness. Politics and Governance, 9(2), 208-218.

Wasserfallen, F., Leuffen, D., Kudrna, Z., \& Degner, H. (2019). Analysing European Union decision-making during the Eurozone crisis with new data. European Union Politics, 20(1), 3-23.

Wendler, F. (2014). Justification and political polarization in national parliamentary debates on EU Treaty reform. Journal of European Public Policy, 21(4), 549-567.

Wendler, F. (2019). The European parliament as an actor and arena of the politics of climate change: Comparing the external and internal dimension. Politics and Governance, 7(3), 327-338.

Zimmermann, H. (2013). The uneasy promise of deposit insurance: Financial globalization and the protection of savers. Competition and Change, 17(3), 265-282.

\section{About the Author}

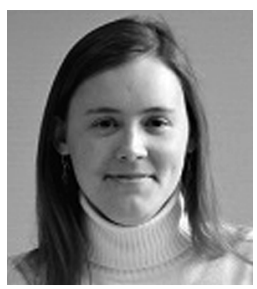

Anna-Lena Högenauer is Assistant Professor in the Institute of Political Science of the University of Luxembourg. She previously worked as Postdoctoral Researcher at Maastricht University and holds a PhD in Politics from the University of Edinburgh. She works on multi-level governance, democracy, and parliamentary control of European policymaking. Her current work focuses on the accountability of the ECB as part of the EMULEG project (The Governance of Monetary Policy: The EMU's Legitimacy Conundrum: https://wwwen.uni.lu/ias/running_audacity_projects/emuleg). 